\title{
Go East Java : A Mobile Application For Tourist Guides In East Java
}

\author{
Umi Saádah ${ }^{1}$, Imam Mustafa Kamal ${ }^{1}$, Fawaati Tsabita ${ }^{1}$, and Vickrilia Yulia $\mathrm{E}^{1}$
}

\begin{abstract}
East Java is one province that has many interesting tourism place to visit, both natural and artificial tourism place. However, information about the tourism places is still less spread in the community. Similarly, information related to various tourist facilities around the place like a resort hotel and villas as well as the kind of eating places such as restaurants. Go East Java is a mobile-based application, which will guide tourists in finding the desired tourist spot. In this application, the user is given the choice of natural and artificial tourism areas. For natural menu there are several options: sea, mountains, waterfalls and caves. While on the artificial menu there are options: temple, religion, zoos and parks. After the user specifies the type, it will display a variety of tourism places in East Java, according to the selected category. Each of these sites will be presented in the form of photos, address, phone numbers and its link. In addition, this application also provides information about the various facilities around the tourism place as well as guide maps. In this case the map to the tourism places is presented by offline and online-based on GPS. This application is expected to be increasingly introducing various tourism places in East Java to both domestic and foreign travelers.
\end{abstract}

Keywords — tourist guide, travelers, mobile application, east java tourism places.

\section{INTRODUCTION}

$\mathrm{E}$ ast Java is a province that can be divided into three plains: the highlands, medium, and low-lying. At each level of the land, there are many interesting sights to visit, both natural and artificial attractions. However, information about the sights, not much publicized in the wider community. As well, information on facilities around the tourist attractions, such as hotel and restaurant. Lots of tourists also do not know the route to get to the sights. Some well-known tourist attractions in East Java as Mount Bromo, Mount Semeru and Papuma [1] beach. While there are still many other attractions that also has potential, but it is less known by the public. Such as beach Goa Cina [2].

Based on data from the central statistics agency in East Java province, visitors tour the province has increased every year. In 2009 , the number of foreign tourists visiting East Java to as many as 155,156 people . Whereas in 2010 increased to 168888 people. Next in 2011 increased to 185,815 people. For domestic tourist visits to eastern Java , in 2009 there were 23,179,713 people, while in the year 2010 increased to 25,148,283 people, and in 2011 increased to 25,148,283 people [3]. More, as shown in Table 1.

From the statistical data that has been listed in Table 1, it can be seen that the visitor attractions in East Java has been quite a lot, although there are many tourist attractions that have not been widely publicized. If the sights are not widely known to have been exposed to the wider community, then it will be able to increase the number of tourist visitors in East Java.

Hopefully, with the increasing number of visitors to tourist attractions, it can indirectly increase revenue in the province of East Java in the tourism sector. Moreover, it will be able to improve the image of the province of East Java in the public eye.

${ }^{1}$ Umi Saádah, Imam Mustafa Kamal, Fawaati Tsabita, and Vickrilia Yulia E are with Departement of Informatics, Politeknik Elektronika Negeri Surabaya, Surabaya, Indonesia. E-mail: umi@eepisits.edu;imam52@gmail.com;tsabita@students.eepis-its.edu; vickriliayulia@student.eepis-its.edum.

\section{METHOD}

In this section, described the solution or the means used to deal with problems that have been described previously.

\section{A. System Design}

Interface design of the Go East Java applications is adopting the design view of Windows 8, which uses the boxes for each button with a simple logo. But, the design combined with the circle button. Overall system design of the application is in accordance with Figure 1.

Based on Figure 1, the user uses the Go East Java applications to see all the tourist attractions available in eastern Java. Detailed information about the tourist places has been stored in the database. Furthermore, users can obtain detailed information about the tourist attractions that have been, in the form of descriptions of tourist attractions as well as restaurants and hotels nearby. In addition, users can use the GPS feature to guide the way to get to the sights that have been chosen.

\section{B. Application Design}

This section describes the design of applications, including the menus and various features in it.

Figure 2 displays the dashboard design as a main page that will appear when the application is run. These pages are designed with 3 menus, namely: 'Go', 'Help' and 'About'. To get into the application, the user selects the menu 'Go'

The next page will appear with a selection of tourist attractions category. Users can select the desired tourist attractions, natural or artificial, as shown in Figure 3.

If the user selects a category of natural attractions, the next page will appear Natural. On this page there are different types of Natural tourist attractions, namely: mounted, waterfall, beach and cave, as seen in Figure 4.

Meanwhile, if the user selects a category of artificial tourist spot, it will show a page of tourism areas. On this page, displayed some artificial tourist attractions, such as parks, religious tourism, temples and zoo, as shown in Figure 5.

Furthermore, if the user selects the type of the natural attractions of the mountain, will show a page that lists 
the mountain [2]. This page contains all the sights of the mountain, which is located in East Java, as shown in Figure 6.

Suppose the user selects Mount Bromo, it will show a page that displays detailed information of the tourist attractions, as shown in Figure 7 . These pages can be scrol down to see more information., as shown in Figure 8.

Included in the detailed information section is a link that contains more information about Mount Bromo. If the user clicks the link, will be more detailed information about Mount Bromo, which appear as in Figure 9. At Mount Bromo tourist page, at the bottom, there are some buttons for information amid the hotel, restaurant and map.

Button hotel, as shown in Figure 10, is used to view hotel information is in near Mount Bromo. If the user clicks the button, the page will appear that explains the description, rates, facilities and hotel website link, as shown in Figure 11.

Restaurant Button as shown in Figure 12, is used to view the information restaurant near Mount Bromo. If the user clicks the button, will appear descriptions of places and the restaurant website links, as shown in Figure 13.

Offline Map button, as shown in Figure 14, is used to view the images offline map of Mount Bromo. While the GPS button, as shown in Figure 15, see the online maps with GPS guidance. In this menu, the user will get a guide direction, starting from the location where the user is located, headed to the tourist attractions to the destination.

If the user clicks on the folder button, the display will be obtained as shown in Figure 16. As for the GPS button, just one example of the page is as shown in Figure 17. This page contains directions to tourist places using Google Map that will show the path begun from where the user is now located to the tourist destination.

\section{RESULT AND DISCUSSION}

This section describes on how the application works, how the tests performed and the results obtained.

\section{A. Testing}

The test is done by using a smartphone with a hardware specifications as shown in Table 2 . While the software specifications used in this testing, as shown in Table 3.

The testing of this application, done by choosing some random travelers. They provide an assessment with a rating scale of 1 to 4 . The results are as shown in Figure 18.

\section{CONCLUSION}

From the results of the testing that has been done, to some randomly selected users, it can be concluded that Go East Java could help the tourists to determine the purpose of the desired tourist attractions in East Java. This application also comes with information about existing facilities around the sights. In addition, this application can also be a guide to get to the sights.

\section{REFERENCES}

[1]. Toejoesatoe, "Referensi Tempat Wisata Jawa Timur," blogspot.com, 1 December 2012. [Online]. Available: http://toejoesatoe.blogspot.com/. [Accessed 2013 December 2013].

[2]. T. W. I. d. Mancanegara, "Tempat Wisata di Jawa Timur Wajib Dikunjungi," 23 October 2013 2013. [Online]. Available: http://www.tempatwisataid.com/853/tempat-wisata-di-jawatimur-wajib-dikunjungi.html. [Accessed 9 December 2013].

[3]. B. P. S. J. Timur, Propinsi Jawa Timur dalam Angka 2012, Surabaya: CV Media Konstruksi, 2012..

[4]. P. Tourism, "Mount Bromo," Eastjava.com, 2012. [Online]. Available: http://eastjava.com/tourism/probolinggo/bromo.html. [Accessed 9 December 2013].

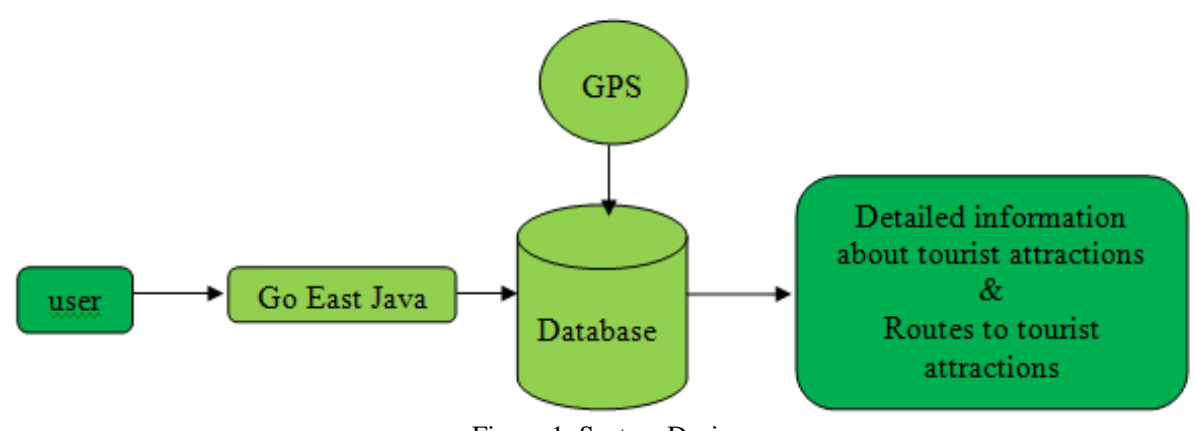

Figure 1. System Design 


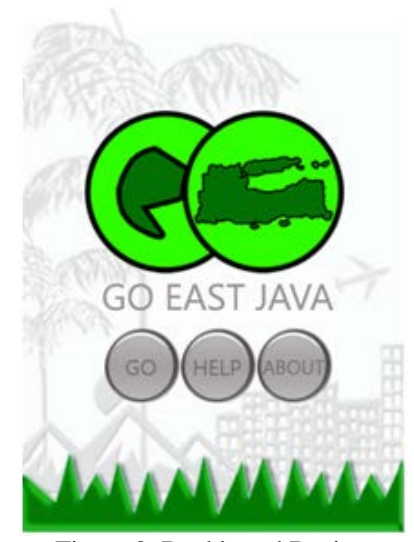

Figure 2. Dashboard Design

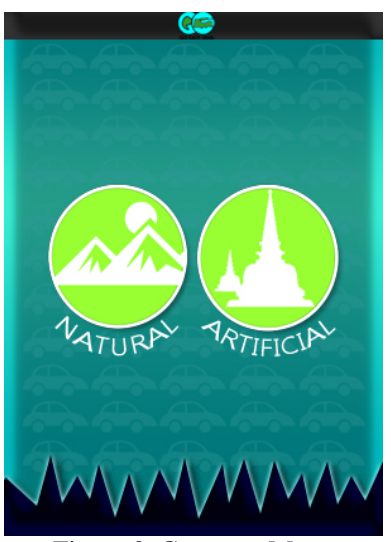

Figure 3. Category Menu

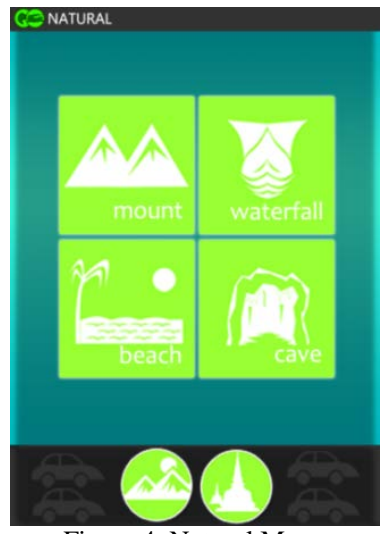

Figure 4. Natural Menu

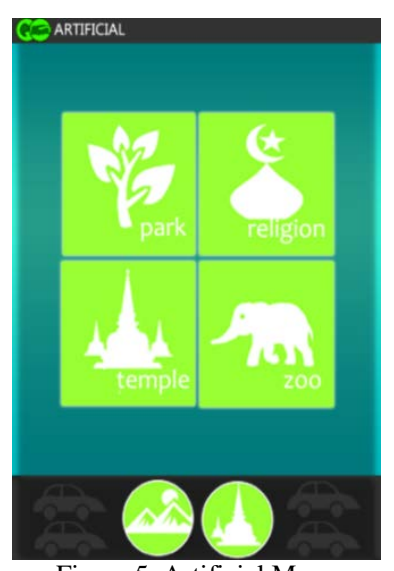

Figure 5. Artificial Menu

\begin{tabular}{|l|}
\hline Mount Kawi \\
\hline Mount Kelud \\
\hline Mount Lawu \\
\hline Mount Raung \\
\hline Mount Sawur \\
\hline Mount Semeru \\
\hline Mount Banyak \\
\hline
\end{tabular}

Figure 6. List of mountains of East Java

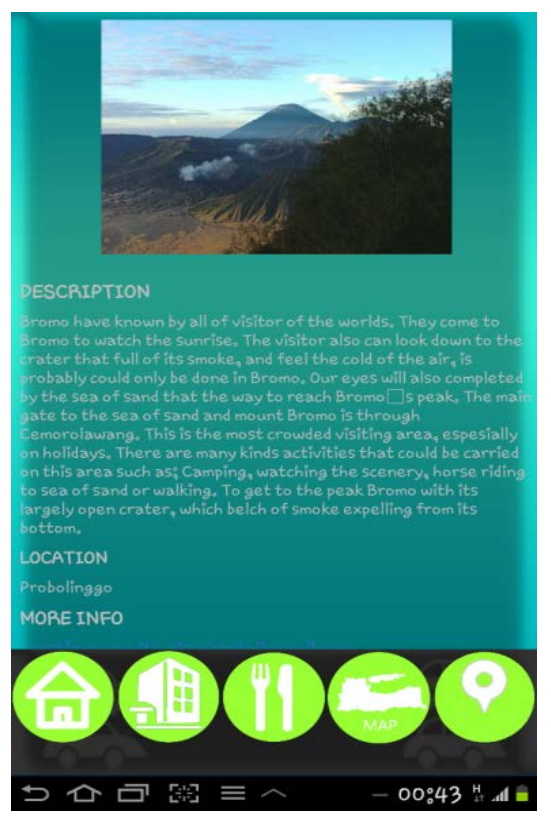

Figure 7. Mount Bromo tourist spot page

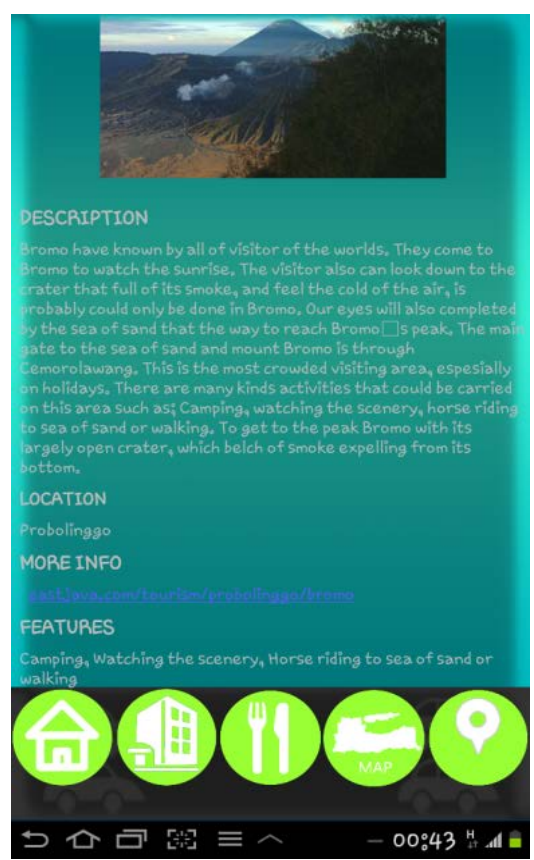

Figure 8. Display when in-scrol down 


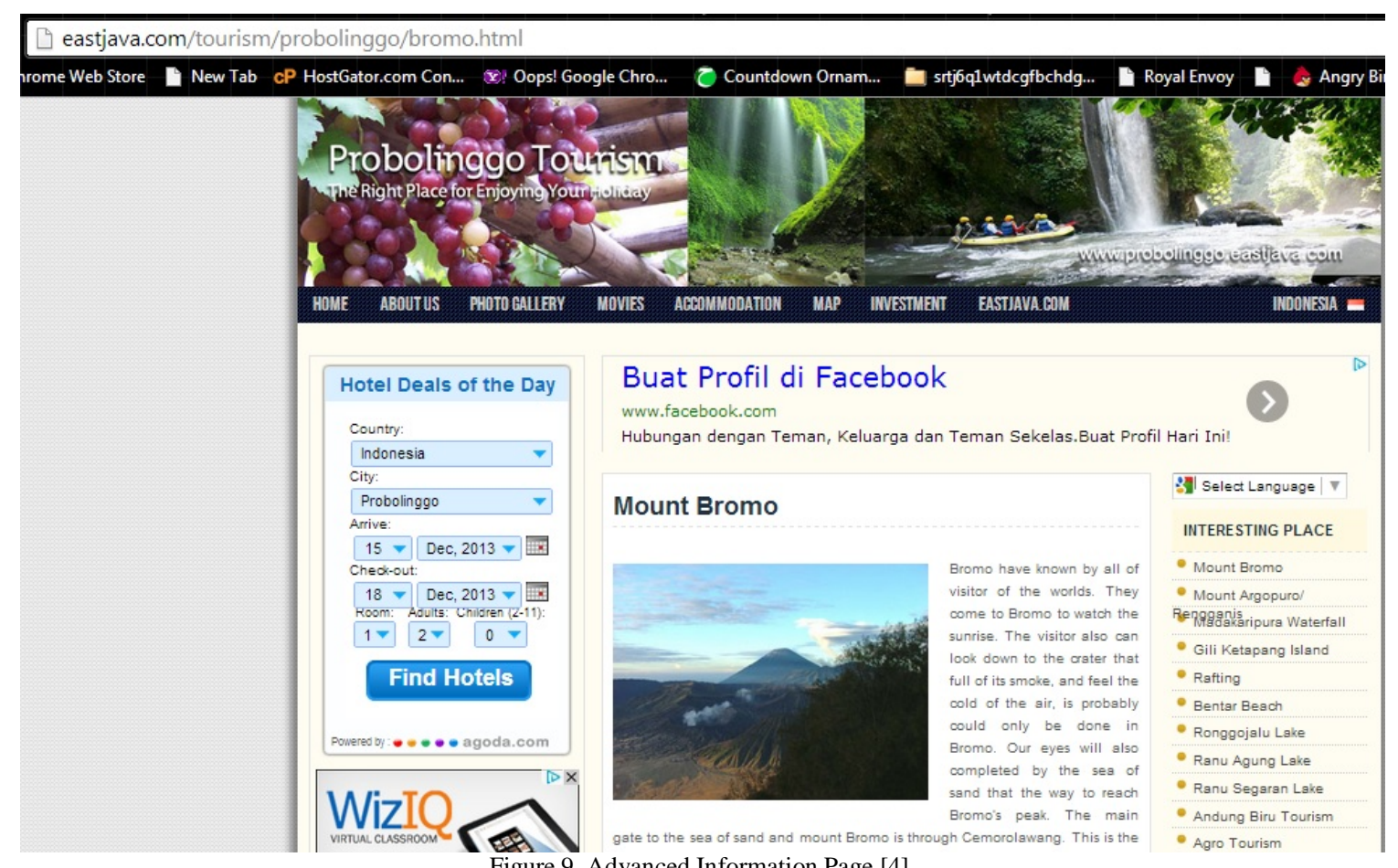

Figure 9. Advanced Information Page [4]

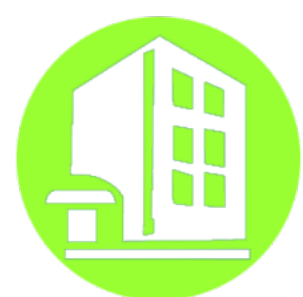

Figure 10. Hotel Button

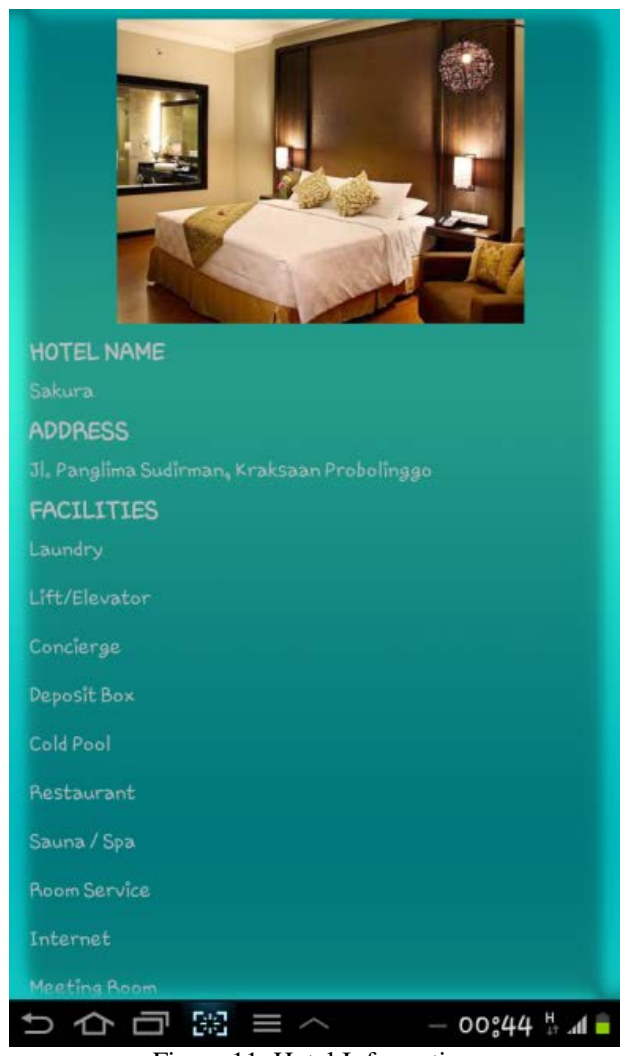

Figure 11. Hotel Information

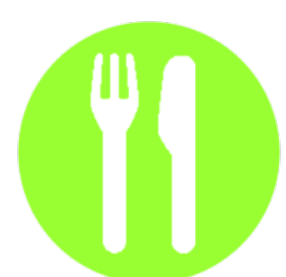

Figure 12. Restaurant Button

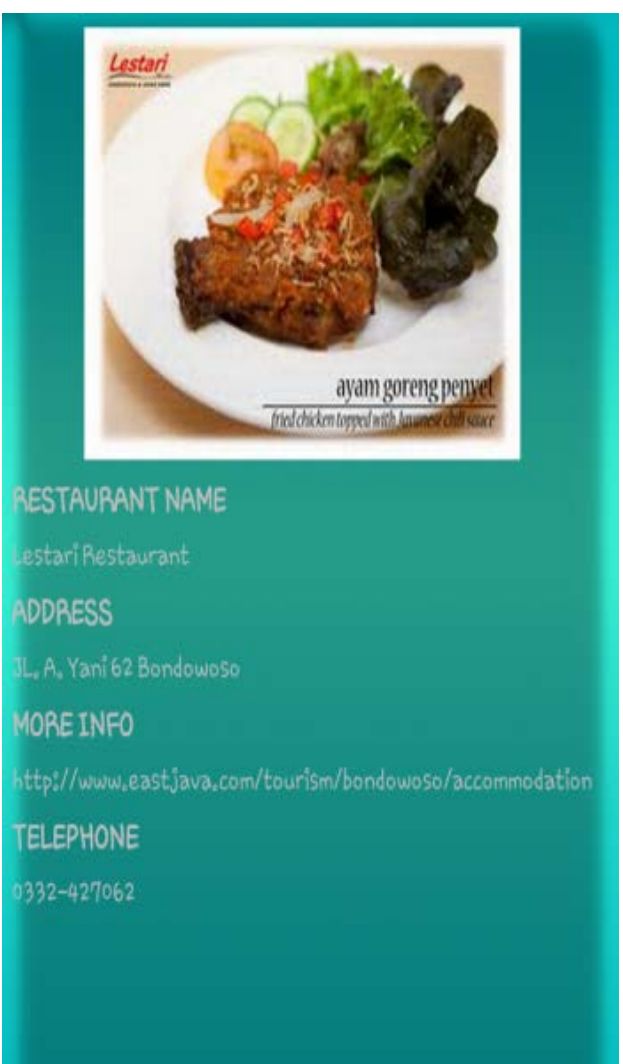

Figure 13. Restaurant Information 


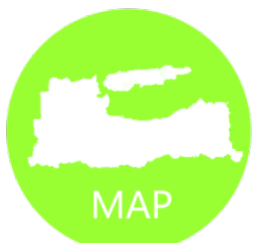

Figure 14. Offline Map Button

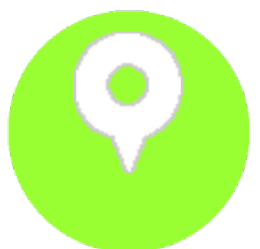

Figure 15. GPS Button

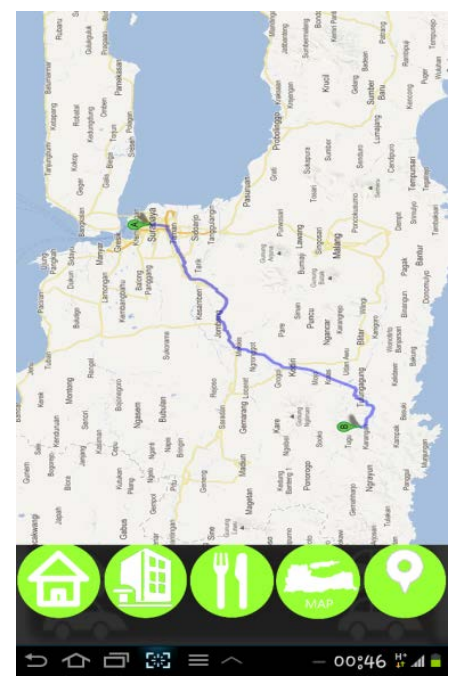

Figure 16. Offline Map of Mount Bromo

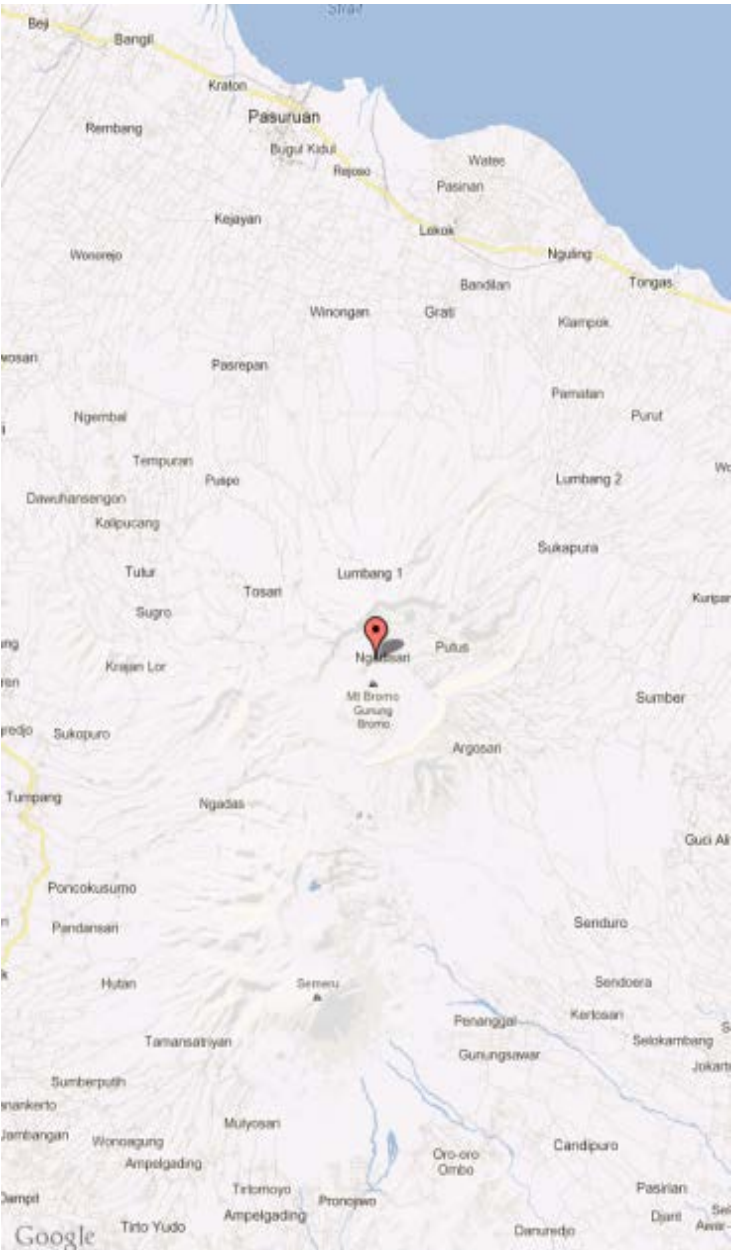

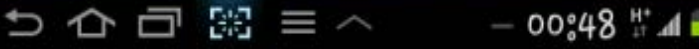

Figure 17. GPS page

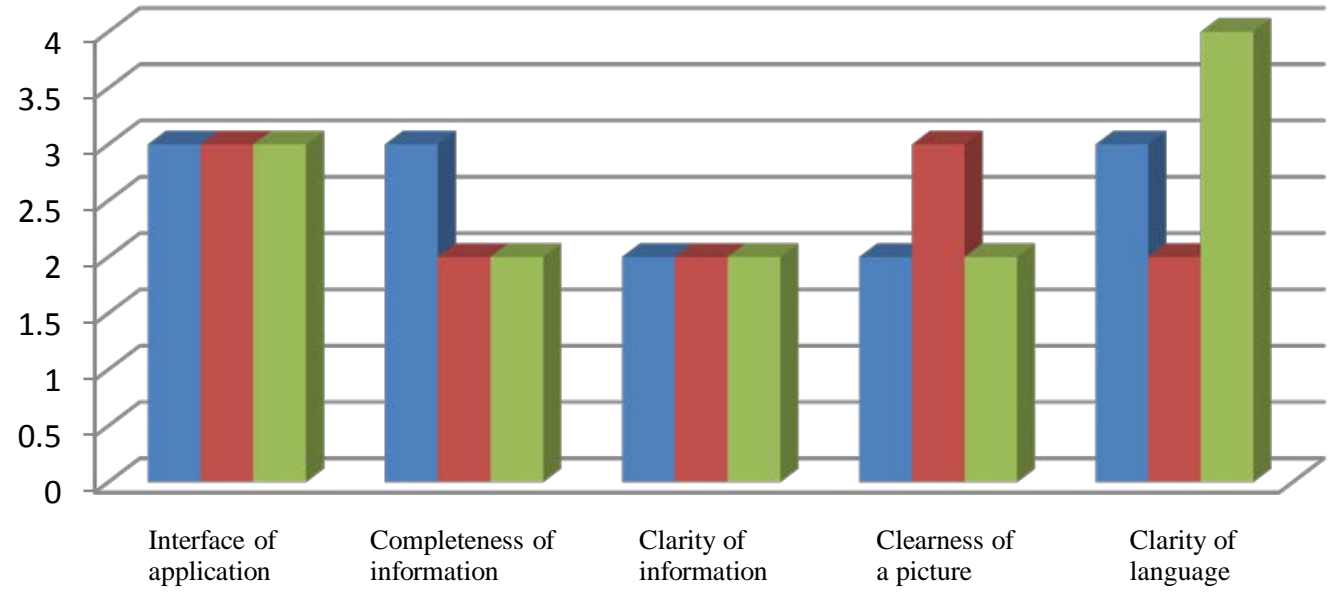

User 1

User 2

User 3

Figure 18. Chart of Testing Results 
TABLE 1.

NUMBER OF DOMESTIC AND FOREIGN TOURISTS [3]

\begin{tabular}{ccc}
\hline \hline Year & Domestic & Foreign \\
\hline 2009 & 23.179 .713 & 155.156 \\
& & \\
2010 & 25.148 .283 & 168.888 \\
& & \\
2011 & 27.116 .853 & 185.815 \\
\hline \hline
\end{tabular}

TABLE 2.

HARDWARE SPECIFICATION

\begin{tabular}{ccl}
\hline No & Name & \multicolumn{1}{c}{ Specification } \\
\hline 1 & Processor & $\begin{array}{l}\text { TI OMAP 4430, CPU Dual-core 1 GHz, } \\
\text { GPU PowerVR SGX540 }\end{array}$ \\
2 & RAM & $1 \mathrm{~GB}$ \\
3 & Type & Galaxy Tab 7.0 \\
4 & Merk & Samsung \\
\hline \hline
\end{tabular}

TABLE 3.

SOFTWARE SPECIFICATION

\begin{tabular}{|c|c|}
\hline \multicolumn{2}{|c|}{ SOFTWARE SPECIFICATION } \\
\hline & Specification \\
\hline $\begin{array}{l}\text { Operating } \\
\text { System }\end{array}$ & $\begin{array}{l}\text { Android OS, v4.0.3 (Ice Cream } \\
\text { Sandwich) }\end{array}$ \\
\hline
\end{tabular}

